\title{
Histology of rectal gonorrhoea in men, with a note on anorectal infection with Neisseria meningitidis
}

\author{
A McMillan, G McNEILlaGE, HM GILMOUR, ${ }^{*}$ FD LEE $\dagger$ \\ From the University Department of Genito-Urinary Medicine, Royal Infirmary, Edinburgh; the *Department \\ of Pathology, University of Edinburgh; and the †University Department of Pathology, Royal Infirmary, \\ Glasgow
}

SUMMARY The histology of the rectal mucosa in 57 men with culturally-proven rectal gonorrhoea is described and the results compared with the findings in biopsies from 57 non-infected men.

An acute inflammatory cell infiltration of the rectal mucosa was found in three $(5 \cdot 3 \%)$ and two (3.5\%) infected and non-infected men respectively. Twenty-one $(36.8 \%)$ men with rectal gonorrhoea and nine $(15.8 \%)$ non-infected men had an increased number of chronic inflammatory cells in the lamina propria.

Gonorrhoea is common in homosexual men who attend clinics for the management of sexually transmitted diseases (STD). ${ }^{12}$ In the United Kingdom in $1977,10 \cdot 9 \%$ of men with gonorrhoea had acquired the infection as a result of homosexual contact ${ }^{3}$ this represented an increase of $1.1 \%$ in the number of cases so acquired in $1971 .^{4}$

Despite the increasing incidence of infection, the histology and immunohistochemistry of rectal gonorrhoea have not been well studied. Harkness ${ }^{5}$ in 1948 described the histological appearance of the mucosa in nine men with presumed rectal gonorrhoea; diagnosis was based solely on the demonstration by microscopy of gonococci in smears of exudate. McMillan and $\mathrm{Lee}^{6}$ found that the microscopic appearance of the mucosa was normal in 10/18 men with rectal gonorrhoea.

The purpose of the present study was to investigate further the histopathology of rectal gonorrhoea.

\section{Patients and methods}

PATIENTS

Fifty-seven men (mean age $27.7 \mathrm{y}$; range 16 to $67 \mathrm{y}$ ) with culturally-proven rectal gonorrhoea were studied. They had attended consecutively clinics held by one of the authors (AMcM) in the Departments of Genito-Urinary Medicine in Glasgow (18 men) and latterly in Edinburgh (39 men). Patients who had gonococcal infection at other sites were not included in the study and men with concomitant gastrointestinal infections were excluded also. Thirteen $(22.8 \%)$ infected men had had gonorrhoea previously; the mean interval (range) between the most recent and the present infection was 36.7 months (2 months to $13 \mathrm{yr}$ ). The duration of the infection (mean 6.9 days, range 4-10 days), was estimated from a consideration of the history given by the patient and his sexual contacts who attended the Department. Biopsy specimens from two men with meningococcal infection of the rectum were available for study.

As a comparison group, 57 men who had had homosexual anal intercourse but who did not have gonorrhoea were investigated. These men were matched as far as possible with the infected patients with respect to age, social class, the number of sexual partners within the preceding six months, the number of years during which anal intercourse had been practised and the interval between the most recent anal coitus and date of rectal biopsy. Six $(10.5 \%)$ of these men had had rectal gonorrhoea previously; the mean interval between the most recent infection and the present clinic attendance was 58.3 months (range 2 months to $10 \mathrm{yr}$ ).

The study was approved by the Ethical Committee of the Lothian Health Board, South District.

\section{CLINICAL METHODS}

A history was obtained from each patient who was asked about symptoms of anal discharge, pruritus 
ani, anorectal bleeding, perianal pain and diarrhoea. After collection of material from the anorectum for microbiological examination, ${ }^{6}$ a sigmoidoscope lightly lubricated with $\mathrm{K}-\mathrm{Y}$ jelly (Johnson and Johnson, Slough, UK) was passed through the anal canal into the rectum. The appearance of the rectal mucosa was recorded according to the system described by Watts et al. ${ }^{7}$

In most patients biopsies were obtained from two different sites in the rectum. These specimens were taken from the anterior and posterior rectal walls about $1 \mathrm{~cm}$ and $5 \mathrm{~cm}$ respectively from the dentate line. When only a single biopsy was performed this was taken from the anterior wall at about $2 \mathrm{~cm}$.

\section{HISTOPATHOLOGICAL METHODS}

The rectal biopsies were fixed in $10 \%$ formol saline and were processed in the usual manner. After obtaining optimal orientation of the specimen, paraffin sections were cut at $4 \mu \mathrm{m}$. Sections were stained routinely with haematoxylin and eosin.

The histological appearance of the rectal mucosa was graded according to the system described by Dickinson et al. ${ }^{8}$ Neither pathologist was aware of the clinical diagnosis in the patient.

Immunoperoxidase method for the demonstration of immunoglobulin-containing plasma cells in the rectal mucosa

The peroxidase-antiperoxidase (PAP) method used was similar to that described by Burns. ${ }^{9}$ Sections were digested at $37^{\circ} \mathrm{C}$ with trypsin $(\mathrm{BDH}$, Poole, UK) $0.4 \%(\mathrm{wt} / \mathrm{vol})$ in $0.4 \%$ (wt/vol) $\mathrm{CaCl}_{2}, \mathrm{pH} 7.6$ for $10 \mathrm{~min}$. Appropriate controls were included in the staining schedule. Rabbit antihuman IgG, IgA and IgM, swine antirabbit IgG and rabbit PAP soluble complexes were obtained from Dakopatts (Denmark). The specificity of the antisera was demonstrated by immunoelectrophoresis. After preliminary evaluation using a chequerboard titration system, the antisera were used at the following dilutions: IgG 1/250; IgA 1/150; IgM 1/150; swine antirabbit IgG 1/20. PAP complexes were used at a dilution of $1 / 50$.

Sections of rectal mucosa from 17 patients, selected at random from amongst these men with rectal gonorrhoea (seven men had grade B changes) and from 17 men with no evidence of infection at any site (seven of these men had grade B changes), were examined.

In addition rectal sections from 10 heterosexual men who attended the Department but who had no anorectal symptoms were studied.

Images of the stained sections were projected on to graph paper and the number of immunoglobulin-containing cells per $1 \mathrm{~mm}$ mucosal length ${ }^{10}$ was counted in each of three consecutive sections.

STATISTICAL METHODS

The $\chi^{2}$ test, with Yates' correction, was used in the comparison of the histological appearance of the rectum in men with gonorrhoea with those who were not infected, and in assessing the influence of duration of infection on the histological pattern.

The Wilcoxon rank test was used in the analysis of the results of the immunoperoxidase staining method.

\section{Results}

\section{HISTOLOGICAL FINDINGS}

The histological appearance of the rectal mucosa was normal (grade A) in $33(57.9 \%)$ of the 57 biop- $\overrightarrow{\vec{O}}$ sies from men with rectal gonorrhoea. A mild to 을 moderate increase in the numbers of lymphocytes and plasma cells in the lamina propria, with neither distortion of the crypt architecture nor marked epithelial changes (grade B), was found in biopsies from $21(36 \cdot 8 \%)$ of the infected patients.

In biopsies from three $(5.3 \%)$ men with gonorrhoea, there was an infiltrate of predominantly acute inflammatory cells in the superficial lamina propria. Migration of polymorphonuclear neutrophils through the crypt epithelium was seen and there were degenerative or reactive changes in the epithelium of the superficial parts of the crypts and surface mucosa (grade $\mathrm{C}$ ).

The biopsy appearances in the 57 non-infected men were graded as follows:

Grade A-46 (80.7\%).

Grade B-9 (15.8\%).

Grade C-2 (3.5\%).

The histological appearance of the rectal mucosa was more commonly abnormal in men with gonorrhoea than in those who were non-infected $\left(\chi^{2}=\right.$ 음 5.937; $\mathrm{p}<0.01)$.

Thirty-two men had been infected for $\leqslant 14$ days; in this group the histological gradings were: grade A -17 men; grade $B-12$ men; grade $\mathrm{C}-3$ men. 5 The histology in men who had been infected for $\geqslant 15 \mathrm{~N}$ days was: grade A-16 men; grade B-9 men; grade N $\mathrm{C}-0$ men. Inflammatory changes in the rectal mucosa did not appear to be related to the duration of infection $\left(\chi^{2}=0.308 ; p>0.05\right)$.

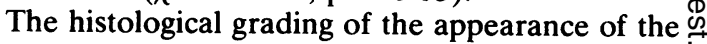
rectum in two men from whom $N$ meningitidis had 0 been isolated were grade $\mathrm{A}$ and grade $\mathrm{B}$ respectively.

\section{CLINICAL FEATURES}

Twenty men with rectal gonorrhoea had symptoms 
Number of $\mathrm{IgM}, \mathrm{IgG}$ and $\mathrm{IgA}$ containing plasma cells per mm length of rectal mucosa in biopsy specimens from men with rectal gonorrhoea, from men with non-gonococcal proctitis and from men with no evidence of infection or proctitis

\begin{tabular}{|c|c|c|c|c|}
\hline \multirow[t]{2}{*}{ Group of patients studied } & \multirow[t]{2}{*}{ No of patients } & \multicolumn{3}{|c|}{$\begin{array}{l}\text { Mean number }( \pm S D) \text { of immunoglobulin-containing plasma cells per mm } \\
\text { length of rectal mucosa }\end{array}$} \\
\hline & & $\overline{I g M}$ & $I g G$ & $\operatorname{Ig} A$ \\
\hline $\begin{array}{l}\text { Rectal gonorrhoea } \\
\text { Grade A } \\
\text { Grade B }\end{array}$ & $\begin{array}{r}7 \\
10\end{array}$ & $\begin{array}{c}6( \pm 3) \\
36( \pm 25)\end{array}$ & $\begin{array}{l}11( \pm 5) \\
23( \pm 9)\end{array}$ & $\begin{array}{l}86( \pm 7) \\
99( \pm 15)\end{array}$ \\
\hline $\begin{array}{l}\text { Non-gonococcal proctitis } \\
\text { Grade B }\end{array}$ & 7 & $29( \pm 21)$ & $23( \pm 26)$ & $122( \pm 20)$ \\
\hline $\begin{array}{l}\text { Controls } \\
\quad \text { Homosexual (Grade A) } \\
\text { Heterosexual (Grade A) }\end{array}$ & $\begin{array}{l}10 \\
10\end{array}$ & $\begin{array}{l}5( \pm 4) \\
7( \pm 2)\end{array}$ & $\begin{array}{l}11( \pm 6) \\
15( \pm 7)\end{array}$ & $\begin{array}{l}85( \pm 7) \\
83( \pm 8)\end{array}$ \\
\hline
\end{tabular}

referable to the anorectal region (13 men had anal discharge, 10 had pruritus ani, seven had bleeding and seven had perianal pain. Seventeen noninfected men had similar symptoms (11 men had pruritus ani, seven had anorectal bleeding, six had anal discharge and one had perianal pain).

The rectal mucosa appeared normal in 48 men $(84.2 \%)$ with gonorrhoea; the mucosa appeared abnormal in the other nine cases; the histological appearance in each being either grade B or C.

Although the rectal mucosa of 15 men showed histological evidence of proctitis (grade B), the sigmoidoscopic appearance was normal. In men whose rectum appeared abnormal macroscopically, the inflammatory changes were found only within $8 \mathrm{~cm}$ of the anal margin and were most prominent just above the dentate line.

IMMUNOPEROXIDASE STAINING OF IMMUNOGLOBULIN-CONTAINING PLASMA CELLS The Table shows the mean number of immunoglobulin-containing plasma cells per $\mathrm{mm}$ mucosal length of rectal biopsy. The mean number of $\operatorname{IgA}, \mathrm{IgG}$ and $\mathrm{IgM}$-containing cells in biopsies from heterosexual men, non-infected homosexual men (grade A histology) and men with rectal gonorrhoea but no significant proctitis (grade A) did not differ significantly. However, there was a significant increase over the latter three groups $(p<0.05)$ in the mean number of $\operatorname{IgA}, \operatorname{IgG}$ and $\operatorname{IgM}$ containing cells in biopsies from infected men showing grade $B$ changes.

Although the mean number of IgA-containing plasma cells in biopsies from patients with nongonococcal proctitis (grade B) is greater than in those from men with rectal gonorrhoea (grade $B$ ), ( $p$ $<0.05$ ) there was no significant difference in the mean numbers of IgM and IgG-containing cells ( $\mathrm{p}>$ $0 \cdot 05)$.

\section{Discussion}

The proctoscopic appearance of the rectal mucosa of men with rectal gonorrhoea was often normal
$(84 \%)$. When there were signs of inflammation, these were confined to the distal rectum (less than $10 \mathrm{~cm}$ from the anal margin) and were particularly prominent just above the dentate line. These observations confirm those of other workers. ${ }^{11} 12$

Histologically, men with gonorrhoea were more likely than non-infected men to show inflammatory changes of the rectal mucosa. These changes were generally mild and consisted of an increase in the number of plasma cells and lymphocytes in the lamina propria. However, in only $42 \%$ of infected men was the histology of the rectum considered abnormal. Almost $20 \%$ of men in whom there was no microbiological evidence of rectal infection with pathogenic bacteria, viruses or protozoa, showed similar inflammatory cell infiltrates of the rectum. This confirms the non-specific nature of the rectal response to gonococcal infection. ${ }^{11}$ Macroscopically the rectum of more than two thirds of men with these mild changes appeared normal.

The severe histological changes described by Harkness in $1948^{5}$ were not found in this study. In his series of nine cases, the diagnosis of gonorrhoea was made by microscopic examination of Gramstained smears of exudate. Facilities for the microbiological detection of gastrointestinal pathogens were not well developed and the patients described may have been infected with other organisms. Similar histological changes have been described ${ }^{13}$ in other gastrointestinal infections including salmonellosis, amoebiasis, shigellosis and campylobacteriosis, all of which are known to occur in homosexual men. ${ }^{14} 15$

Why the histology of the rectal mucosa should be normal in more than $50 \%$ of infected men is not clear. It might be argued that the biopsy had been taken before there was sufficient time for the body to mount an inflammatory response or that the disease had progressed beyond the acute stage and that evidence of previous inflammation would have resolved. However, in the present study, there appeared to be no correlation between the duration of the infection and the histological appearance. 
In patients with ulcerative colitis, there is an increase in the number of IgG-containing plasma cells in the lamina propria of the rectum; the number of cells appear proportional to the activity of the inflammation. ${ }^{10}$ The patients studied here had relatively mild inflammatory changes and the numbers of IgG-containing cells did not approach those found in idiopathic ulcerative proctocolitis. In tissue sections from each patient with rectal gonorrhoea, IgA-containing cells predominated.

Neisseria meningitidis can be isolated from the anal canal of about $2 \%$ of men who have had homosexual contact. ${ }^{16}$ We had the opportunity of examining rectal tissue from two men with meningococcal infection and found a mild chronic inflammatory cell infiltration of the lamina propria in one man. As about $20 \%$ of men who have had anal intercourse show similar changes $^{6}$ the significance of this latter finding is uncertain.

\section{References}

' Fluker JL. A 10-year study of homosexually transmitted infection. Br J Vener Dis 1976;52:155-60.

${ }^{2}$ McMillan A, Robertson DHH. Sexually transmitted diseases in homosexual males in Edinburgh. Health Bull 1977;35:266-71.

${ }^{3}$ British Co-operative Clinical Group. Homosexuality and venereal disease in the United Kingdom: A second study. $\mathrm{Br} J$ Vener Dis 1980;56:6-11.

${ }^{4}$ British Co-operative Clinical Group. Homosexuality and venereal disease in the United Kingdom. $B r J$ Vener Dis 1973;49:329-37. ${ }^{5}$ Harkness AH. Anorectal gonorrhoea. Proc $R$ Soc Med
1948;41:476-8.

- McMillan A, Lee FD. Sigmoidoscopic and microscopic appearance of the rectal mucosa in homosexual men. Gut 1981;22:1035-41.

' Watts J McK, Thompson H, Goligher JC. Sigmoidoscopy and cytology in the detection of microscopic disease of the rectal mucosa in ulcerative colitis. Gut 1966;7:288-94.

${ }^{8}$ Dickinson RJ, Gilmour HM, McClelland DBL. Rectal biopsy in $\stackrel{\overrightarrow{\mathbb{Q}}}{\mathrm{Q}}$ patients presenting to an infectious disease unit with diar- $\varrho$ rhoeal disease. Gut 1979;20:141-8.

${ }^{9}$ Burns J. Immunohistochemical methods and their application in the routine laboratory. In: Anthony PP, Woolf N, eds Recent advances in histopathology. 10th ed. Edinburgh, London: Churchill Livingstone, 1978:337-50.

${ }^{10}$ Rosekrans PCM, Meijer CJL, Van der Wal AM, Cornelisse CJ, Lindeman J. Immunoglobulin containing cells in inflammatory bowel disease of the colon: a morphometric and immunohistochemical study. Gut 1980;21:941-7.

" Klein EJ, Fisher LS, Chow AW, Guze LB. Anorectal gonococcal or infection. Ann Intern Med 1977;86:340-6.

${ }^{12}$ Lebedeff DA, Hochman EB. Rectal gonorrhoea in men: $\vec{A}$ diagnosis and treatment. Ann Intern Med 1980;92:463-6.

${ }^{13}$ Day DW, Mandel BK, Morson BC. The rectal biopsy appearances in Salmonella colitis. Histopathology 1978;2:117-31.

${ }^{14}$ Felman VM, Ricciardi NB. Sexually transmitted enteric diseases Bull NY Acad Med 1979;55:532-9.

${ }^{15}$ Quinn TC, Corey L, Chaffee RG, Schuffler MD, Holmes KK. Campylobacter proctitis in a homosexual man. Ann Intern Med 1980;93:458-9.

${ }^{16}$ Judson FN, Ehret JM, Eickhoff TC. Anogenital infection with Neisseria meningitidis in homosexual men. J Infect Dis 1978;137:458-63.

Requests for reprints to: Dr A McMillan, Department of Genito-Urinary Medicine, Royal Infirmary, Wards 45/46 Edinburgh EH3 9YW. Scotland. 